\begin{tabular}{|c|c|c|}
\hline Beitr. Ent. & Keltern & ISSN 0005-805X \\
\hline $\mathbf{5 3}(2003) 1$ & S. $131-139$ & 31.07 .2003 \\
\hline
\end{tabular}

\title{
First descriptions of two new amber species of Cyphomyrmex from Mexico and the Dominican Republic
}

\section{(Hymenoptera: Formicidae)}

With 2 figures

\author{
MARIA L. DE ANDRADE
}

\section{Summary}

Two new amber species of Cyphomyrmex represented by a single specimen each are described. C. maya n. sp. is based on a single worker from Mexican amber. C. taino n. sp. is described on an alate gyne from Dominican amber. C. maya and taino are members of the rimosus group of KEMPF (1964) and of the foxi subgroup of SNELLING \& LONGINO (1992). Among the two known Jamaican representatives of the foxi subgtoup, C. maya resembles foxi. The worker of maya shares with the one of foxi developed mesosomal spines. C. maya can be easily differentiated from foxi mainly by the propodeum profile with two spiniform teeth instead of a longitudinal carina forming two succeeding obtuse teeth, by the shorter scapes, by the postpetiole with smaller and less pointed dorsal projections and by the smaller size. The gyne of taino resembles the gyne of foxi in general shape, but taino differs from foxi by its smaller size, by the shorter scapes and by the postpetiole with lower, much smaller and rounded dorsal projections. The gyne of taino also resembles the worker of maya in head shape, but taino can be easily distinguished from maya by the denser pilosity and sculpture.

\section{Zusammenfassung}

Zwei neue fossile Arten von Cyphomyrmex aus Bernstein, jede durch ein einzelnes Exemplar belegt, werden beschrieben. C. maya basiert auf einer einzelnen Arbeiterin aus Mexikanischem Bernstein. C. taino wird nach einer geflügelten Gyne aus Dominikanischem Bernstein beschrieben. C. maya und C. taino gehören zur rimosus-Gruppe sensu KEMPF (1964) und innerhalb dieser zur foxi-Subgruppe sensu SNELLING \& LONGINO (1992). Von den beiden bekannten jamaikanischen Vertretern der foxi-Subgruppe ähnelt C. maya vor allem C. foxi. Die Arbeiterinnen beider Arten besitzen gut ausgebildete mesosomale Dornen. C. maya kann von C. foxi vor allem durch das Profil des Propodeum leicht unterschieden werden, das zwei dornförmige Zähne trägt anstatt zweier Längskiele, die nur undeutliche Zähnchen bilden, durch einen kürzeren Scapus, durch kürzere und weniger scharf zugespitzte dorsale Fortsätze des Postpetiolus und durch die geringere Größe. Das äußere Erscheinungsbild der Gyne von C. taino ähnelt der Gyne von C. foxi, wobei sich C. taino von $C$. foxi durch die geringere Größe, einen kürzeren Scapus und durch einen Postpetiolus mit kürzeren, deutlich kleineren und abgetundeten dorsalen Fortsätzen unterscheidet. Bezüglich der Form des Kopfes gleicht die Gyne von $C$. taino auch dex Arbeiterin von $C$. maya, aber $C$. taino kann leicht von $C$. maya durch die dichtere Behaarung und Skulptur unterschieden werden. 


\section{Introduction}

The fungus-growing ant genus Cyphomymex MAYR is represented by 37 valid names (see the literature review by BOLTON, 1995). KEMPF's $(1964,1966)$ revisions of the genus divided the species in two groups, the strigatus group (15 species) and the rimosus group (16 species). KEMPF's (1966) revision of the rimosus group left unresolved the status of 16 infraspecific names assigned to C. rimosus. Later on, KEMPF (1968) described another new species belonging to the rimosus group. SNELLING \& LONGINO (1992) revised the group with particular attention to the rimosus group and its infraspecific forms. According to SNELLING \& LONGINO (1. c.) this group comprises 21 valid species which can be ordered into 6 subgroups. MACKAY \& BAENA (1993) described a new species to the rimosus group of KEMPF (1966) and attributed it to the salvini subgroup of SNELLING \& LONGINO (1992). The colonies of Cyphomymex are composed by some 500 workers at most and they are commonly in soil or in rotting wood on the ground, in the leaf-litter, in dead, decaying tree limbs, in matts of moss on tree trunks, or within epiphytic pseudobulbs. The fungus gardens of Cyphomyrmex are grown on insect faeces and bits of debris (SNELLING \& LONGINO, 1992).

BROWN (1973) recorded the presence of winged myrmicines resembling males of Mycetosoritis (another attine genus) in Chiapas amber. BARONI URBANI (1980) was the first to describe a fossil Attini from Dominican amber. BARONI URBANI (1. c.) described a new species of Trachymymex. T. primaevus BARONI URBANI is the sole amber species of true Attini known in detail to date. The following authors, however, also refer to amber Attini without describing them: WILSON (1985) records the presence of Cyphomymex in Dominican amber and BARONI URBANI (1995) records the presence of Apterostigma and Cyphomyrmex in Dominican amber.

\section{Material and Methods}

The following specimens of Cyphomymex have been examined in two amber samples, one from Mexico and one from the Dominican Republic:

\section{Mexican amber}

From the collection of Dr. George O. Poinar Jt. (GOPC) deposited at the Oregon State University, Corvallis, Oregon.

H-10-223 (Fig. 1). An orange-brown sample, originally $2.5 \times 1.7 \mathrm{~cm}$, containing one Cyphomyrmex worker and few impurities. The preservation condition of the ant is good and its study is only slightly hindered by a longitudinal fissure on the right side of the head.

\section{Dominican amber}

From the Museum of Comparative Zoology (MCZC), Harvard University, Massachusetts, USA.

The MCZC Cyphomymrex specimen has been arbittarily numbered as MCZC-36. The numbers 1 to 24 were already used for MCZC amber material in the Cephalotes revision (ANDRADE \& BARONI URBANI, 1999) and the numbers 25-35 in the Proceratium revision (BARONI URBANI \& ANDRADE, 2003). The Cyphomymmex gyne described here is of particular interest since it bears a precise locality label with the name of the mine of provenance. The location of the amber mines mentioned here can be found in the maps published by BARONI Urbani \& SAUNDERS (1982) and by POINAR (1992). 
MCZC-36 (Fig. 2). A small dark orange sample $1.4 \times 1.3 \mathrm{~cm}$ from El Valle. It contains an alate gyne of Cyphomyrnex, one insect larva and impurities. The preservation condition of the ant is good but air bubbles and longitudinal lines disturb in part its vision.

The amber of $\mathrm{El}$ Valle should be a relatively young one according to POINAR (1992): 20-30 Mio years B. P.

Measurements used in the text are defined here as:

HL Head length: the maximum measurable distance between the medial margin of vertex and the antero-medial margin of clypeus with the head in full frontal view.

HW Head width: maximum head width behind the eyes with the head in full frontal view.

EL Eye length: maximum length of the eye.

SL Scape length: length of scape shaft, excluding the basal condyle.

ML Mandibular length, minimum distance between the external mandibular articulation and its apical tooth.

$\mathrm{HBaL}$ Maximum length of hind basitarsus measured on its external face.

HTiL Maximum length of hind tibia measured on its external face.

HFeL Maximum length of hind femur measured on its external face.

WL Weber's length: diagonal length of mesosoma from the anterior pronotal border to the distal edge of the propodeal lamellae.

TL Total length: combined head length in full face view (closed mandibles included), Weber's length of mesosoma, petiole length (in side view), postpetiole length (in side view) and length of gaster (in side view).

The descriptions below follow those of $\operatorname{KEMPF}(1964,1966)$ and SNELLING \& LONGINO (1992).

Results

Cyphomyrmex maya DE ANDRADE sp. n.

Fig. 1

Holotype: worker from Mexican amber, labelled: H-10-223, in the GOPC.

Derivatio nominis: this species is named after the Maya, the ancient inhabitants of Chiapas. Maya is used as a name in apposition.

\section{Diagnosis}

A Cyphonymex species, similar to foxi but differing from it, in the worker, by the propodeum with two pairs of spiniform teeth instead of with a pair of longitudinal carinae forming two obtuse teeth in profile, and by its shorter scapes.

\section{Description}

Worker. Head shape as in Fig. 1. Mandibles with very thin longitudinal rugosities. Masticatory margin of the mandibles with 4 small teeth and a pointed apical one. Clypeus with convex anterior margin. Lateral teeth of clypeus acute and clearly visible in full face view. Margin of frontal lobes rounded. Dorsal portion of the frontal carinae high, well marked and diverging to the vertexal corners. Submedian carinae of vertex marked, subparallel and delimiting an impression. Preocular carina curved messaly in front of the eye. Postocular carina marked, reaching the tip of the vertexal corner. Supraocular tubercle minute. 

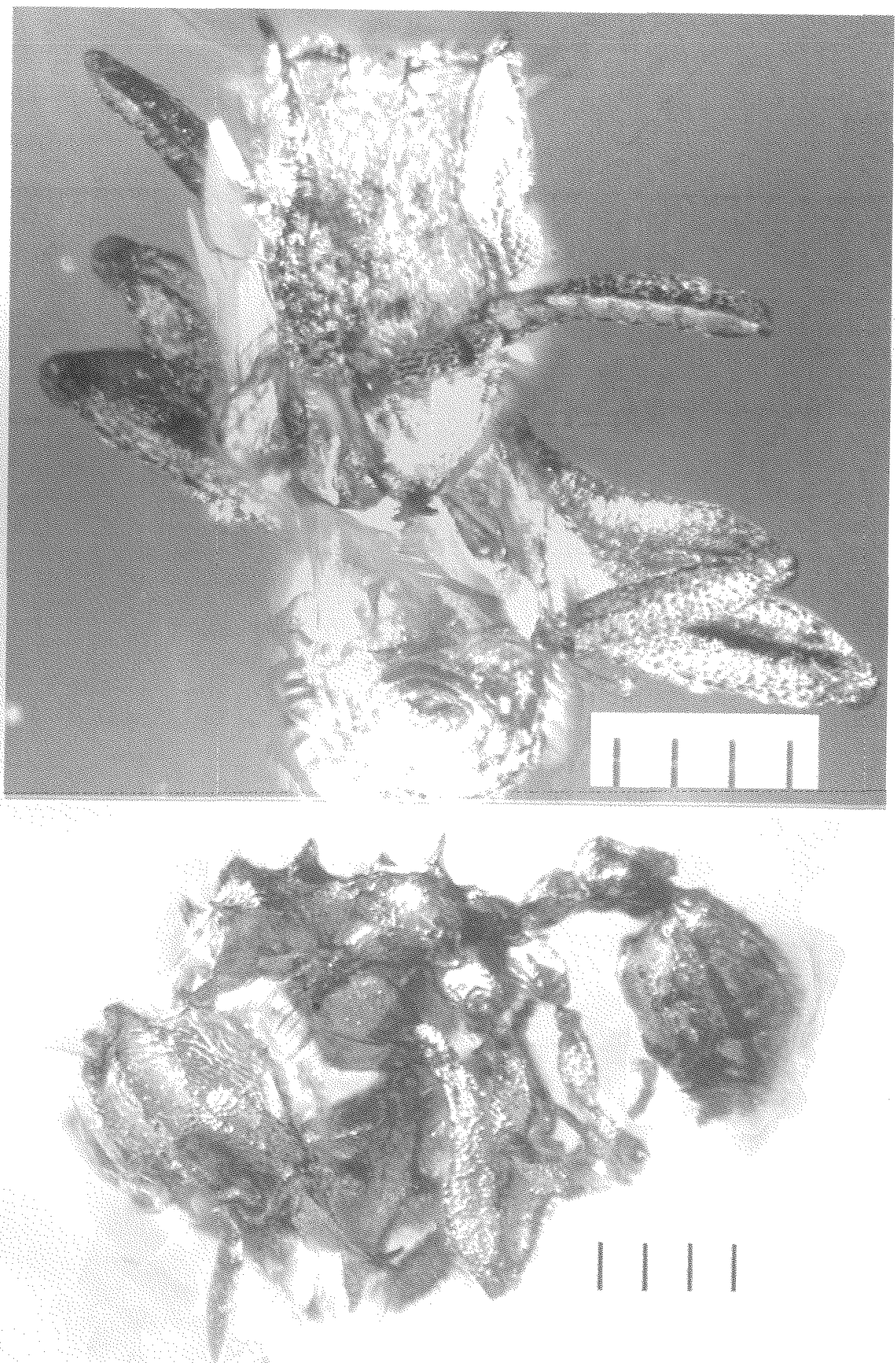

Fig. 1. Cypbomyrmex maya n. sp. worker. From Mexican amber: head in dorsal view (top), and profile of the whole specimen (bottom). Distance between two scale bars $0.1 \mathrm{~mm}$. 
Vertexal corners with projecting spine-like process. Vertexal margin in frontal view laterally gently convex, strongly carinate and connected to the submedian carinae. Vertexal margin behind the submedian carinae concave and not carinate. Posterior genal margin with a thin carina below the lower eye margin and continuing to the mandibular base. Scape slightly surpassing the vertexal corners by a distance of less than its maximum diameter. All funicular joints longer than broad. Eyes with about 9 facets on their greatest diameter.

Mesosoma. Submedian pronotal tubercles developed; lateral tubercles about as long as the submedian ones. Humeral ridges superficially marked and reaching the lateral tubercles. Anterior pair of mesonotal tubercles stout and subequal to the posterior spiniform pair. Mesometanotal impresson broad and shallow. Basal face of the propodeum with a small pair of spines. Declivous face of the propodeum with a pair of large spiniform teeth. Hind femora ventrally gently angulate at their basal-third and with a postero- distal carina.

Petiole. Petiolar node with a pair of postero-dorsal lamellae. Postpetiole broad, bearing a pair of postero-dorsal salient lobes with subround tip. Dorsum of the first gastral segment with a short antero-median impression. Lateral margins of first gastral segment superficial.

Sculpture. Integument opaque. Head granulate-punctate and with thin, slightly longitudinal rugosities on the frontal area. Mesosoma, petiole and postpetiole punctate and with rare, small granulation. Legs punctate-granulate. Gaster punctate and with large, slightly sparse granules.

Pilosity sparse, simple and curved.

Colour. Dark brown.

Measurements in $\mathrm{mm}$ and Indices: TL 2.42; HL 0.57; HW 0.52; EL 0.14; ML 0.35; SL 0.55; WL 0.74; HFeL 0.64; HTiL 0.47; HBaL 0.36.

Material examined: Mexican amber: 1 worker (holotype), H-10-223 [GOPC].

\section{Cyphomyrmex taino DE ANDRADE sp. n.}

Fig. 2

Holotype: alate gyne from Dominican amber, labelled: MCZC-36, in the MCZC.

Derivatio nominis: Taino, the name of the first inhabitants of the island of Hispaniola is used as a name in apposition.

\section{Diagnosis}

A Cypbomymex species similar to foxi, but differing from it, in the gyne, by its smaller size (TL $=3.02 \mathrm{~mm}$ instead of $3.4 \mathrm{~mm}$ as given by WHEELER, 1917), by the shorter scapes, by the propodeal sides with a pair of obtuse teeth slightly differentiating the basal and declivous faces instead of propodeal sides with a pair of longitudinal ridges ending posteriorly in large teeth, and by the postpetiole with smaller dorsal projections.

\section{Description}

Gyne. Head shape as in Fig. 2. Mandibles with very thin longitudinal rugosities. Masti catory margin of the mandibles with 4 small median teeth and a pointed apical one. Clypeus with convex anterior matgin. Lateral teeth of clypeus small, obtuse and visible in full face view. 


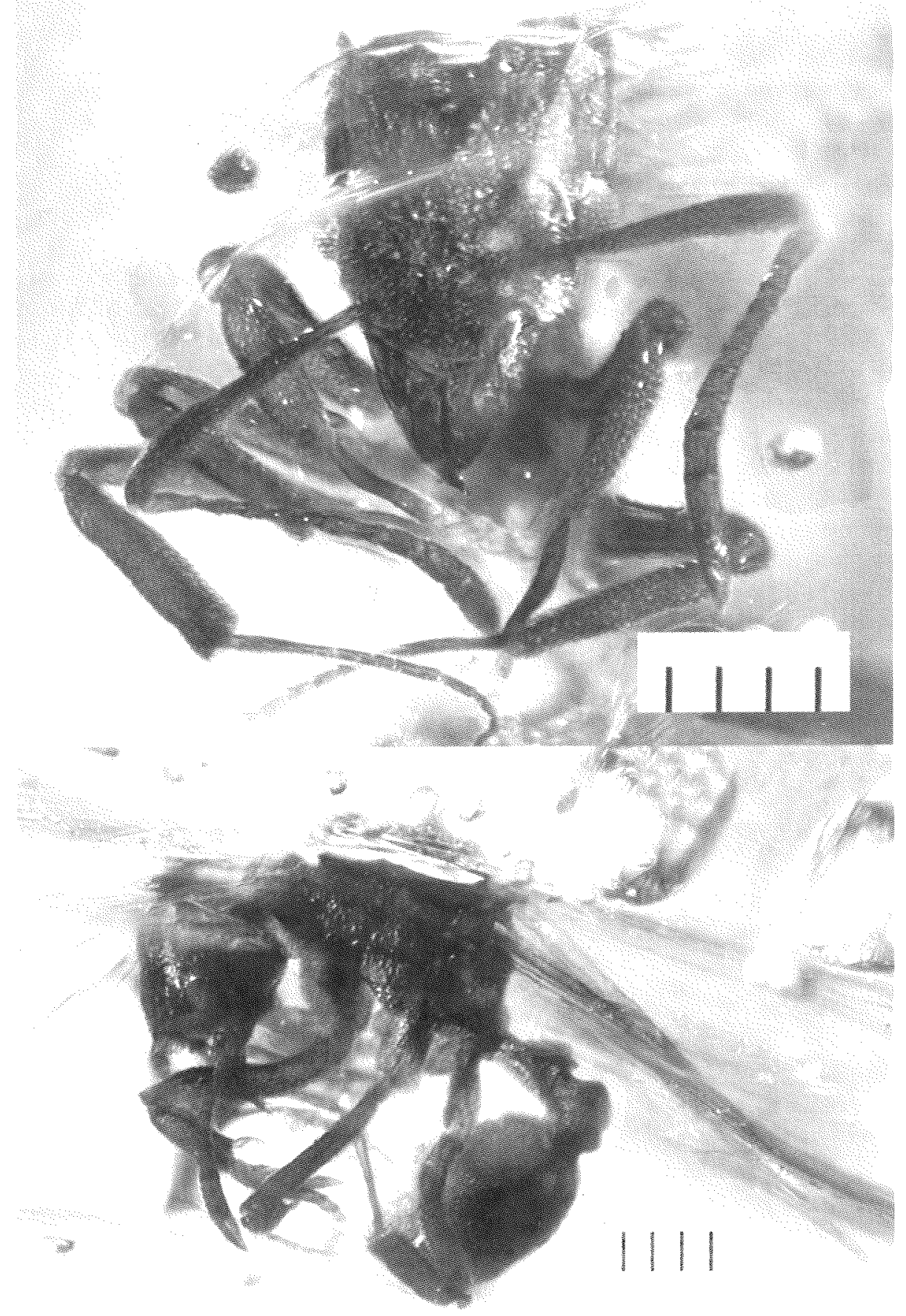

Fig. 2. Cyphomymex taino n. sp. gyne. Dominican amber: head in dorsal view (top), and profile of the whole specimen (bottom). Distance between two scale bars $0.1 \mathrm{~mm}$. 
Margin of frontal lobes rounded. Dorsal portion of the frontal carinae high, well marked and diverging to the vertexal corners. Submedian carinae of vertex marked, subparallel and delimiting an impression. Preocular carina forming a small denticle below and curved mesally in front of the eyes. Postocular carina marked, reaching the tip of the vertexal corner. Supraocular tubercle absent. Vertexal corners with projecting spine-like process. Vertexal margin in frontal view laterally straight, superficially carinate and connected to the submedian carinae. Vertexal margin behind the submedian carinae concave and not carinate. Posterior genal margin with a thin carina below the level of the eyes continuing to the mandibular base. Scapes slightly surpassing the apex of the vertexal corners by a distance of their maximum diameter. All funicular joints longer than broad. Impair ocellus in front of the submedian carinae and pair ocelli on their outer face. Eyes with about 12 facets on their greatest diameter.

Mesosoma. Lateral pronotal tubercles salient and obtuse. Mesonotum dorsally with traces of a Y-shaped sulcus. Posterior two thirds of the mesonotal sides with a longitudinal ridge in shape of two round teeth. Scutellum posteriorly bidentate. Propodeum with slightly differentiated basal and declivous faces. Basal face of the propodeum short and declivous posteriorly. Declivous face of the propodeum flat. Each side between the basal and declivous faces with an obtuse tooth.

Petiole. Petiolar node with a pair of postero-dorsal ridges pointed posteriorly. Postpetiole broad, bearing a pair of postero-dorsal longitudinal ridges shaped posteriorly as a small, round lobe. Dorsum of the first gastral segment with a short antero-median impression. Lateral margin of first gastral segment superficial.

Wings semitransparent with darker veins. Venation as in Fig. 43 of KEMPF (1964).

Sculpture. Integument opaque. Head, mesosoma, petiole, postpetiole and legs granulate and minutely areolate.

Pilosity dense and whitish, with simple, curved hairs on the frontal carinae, on the scapes and on the legs and with a mixture of scale-like and simple curved hairs on the remaining body parts except on the funicular joints. Funicular joints with very thin, short, appressed hairs.

Measurements in mm and Indices: TL 3.02; HL 0.62; HW 0.57; EL 0.17; ML 0.39; SL 0.65; WL 0.94; HFeL 0.82; HTiL 0.61; HBaL 0.43.

Material examined: Dominican amber from El Valle: 1 alate gyne (holotype), MCZC36 [MCZC].

\section{Discussion}

The two new amber Cyphomyrmex described in this paper belong clearly to the foxi subgroup as defined by SNELLING \& LONGINO (1992). The foxi subgroup comprises only two recent species, foxi and podargus, both known only from Jamaica. SNELLING \& LONGINO (1. c.) listed five characters for the foxi subgroup, two of which may be better appreciated in the workers only. The two fossil Cypbomyrmex species, maya and taino, share with the two recent Jamaican species, the following worker and gyne characters: preocular carina curved mesally in front of the eyes; antennal scrobes subopaque and 
indistinctly granulose; antennal scapes surpassing the vertexal corners. In addition the worker of maya shares with the workers of foxi and podargus the lateral pronotal tubercles long and spine-like and submedian tubercles present. Both fossil Cyphomyrmex described in this paper share with the recent foxi only the breadth of the frontal lobes narrower than the distance between the inner margins of the eyes.

It is noteworthy that both fossil Cyphomymex described in this paper from Mexico and from Dominican Republic have their closest relatives in Jamaica. This may be explained, at least in part, by the relatively young age of the Dominican amber from El Valle from which taino was collected.

\section{Acknowledgements}

I would like to express my warmest thanks to Dr. George O. Poinar Jr. and Stefan P. Cover for providing these and many other interesting amber samples. Prof. Dr. Cesare Baroni Urbani contributed to this paper by critically reading the manuscript.

\section{References}

ANDRADE, M. L. (DE) \& BARONI URBANI, C. 1999: Diversity and adaptation on the ant genus Cephalotes, past and present. - Stuttgarter Beiträge zur Naturkunde, B 271: 1-889.

BARONI URBANI, C. 1980: First description of fossil gardening ants (Amber Collection Stuttgart and Natural History Museum Basel; Hymenoptera: Formicidae. I: Attini). - Stuttgarter Beiträge zur Naturkunde, B 54: 1-13.

BARONI URBANI, C. 1995: Invasion and extinction in the West Indian ant fauna revised: the example of Pheidole (Amber Collection Stuttgart: Hymenoptera, Formicidae. VIII: Myrmicinae, partim). - Stuttgarter Beiträge zur Naturkunde, B 222: 1-29.

Baroni Urbani, C. \& ANDrade, M. L. (DE) 2003: The ant genus Proceratium in the Extant and fossil record (Hymenoptera: Formicidae). Museo Regionale di Scienze Naturali-Torino. - Monografie No. 36 (in press).

BARONI URBANI, C. \& SAUNDERS, J. B. 1982: The fauna of Dominican Republic amber: the present status of knowledge. - Trans. Ninth Caribbean Geological Conference Santo Domingo (1980), Dominican Republic 1: 213-223, 1 pl.

BOLTON, B. 1995: A new general catalogue of the ants of the world. - 504 pp. Cambridge/Massachusetts (Harvard University Press).

BROWN, W. L. JR. 1973: A comparison of the Hylean and Congo-West African rain forest ant faunas. - In: MEggers, B. J., AYensu. E. S. \& DUCKWORTH, W. D. (eds.): Tropical forest ecosystems in Africa and South America, a comparative review. Pp. 161-185. Washington, D. C. (Smithsonian Institution Press).

KEMPF, W. WW. 1964: A revision of the Neotropical ants of the genus Cyphomymex MAYR. Part I: Group of strigatus Mayr (Hym. Formicidae). - Studia Entomologica 7: 1-44.

KEMPF, W. W. 1966: A revision of the Neotropical fungus-growing ants of the genus Cyphomyrmex MAYR.

Part II: Group of rimosus (Spinola) (Hym. Formicidae), - Studia Entomologica 8: 161-200.

KEMPF, W. W. 1968: A new species of Cypbomyrmex from Colombia, with further remarks on the genus. (Hymenoptera, Formicidae). - Revista Brasileira de Entomologia 28: 35-41.

MACKAY, W. P. \& BAENA, M. L. 1993: A new "horned" fungus growing ant, Cyphomyrmex castagnei, from Colombia (Hymenoptera: Formicidae). - Sociobiology 23: 31-37.

PoINAR, G. O. JR. 1992: Life in amber. 350 pp., 8 pls. Stanford/California (Stanford University Press).

SNELIING, R. R. \& LONGINO, J. T. 1992: Revisionary notes on the fungus-growing ants of the genus Cyphomyrmex, rimosus group (Hymenopteta: Formicidae: Attini). - In: QUNTERO, D. \& AIELLO, A. (eds.): Insects of Panama and Mesoamerica: selected studies. Pp. 479-494. Oxford (Oxford University Press). 
WheeLer, W. M. 1917: Jamaican ants collected by Prof. C. T. Brues. - Bulletin of the Museum of Comparative Zoology 61: 457-471.

WrLSON, E. O. 1985: Ants of the Dominican amber (Hymenoptera: Formicidae). 1. Two new myrmicine genera and an aberrant Pbeidole. - Psyche 92: 1-9.

\author{
Authors' address: \\ Dr. MARIA L. DE ANDRADE \\ Institut für Natur-, Landschafts- und Umweltschutz \\ Universität Basel \\ Biogeographie \\ Neuhausstrasse 31 \\ $\mathrm{CH}-4057$ Basel \\ Switzerland
}

\title{
Besprechungen
}

BÄHrManN, R.: Die Mottenschildläuse: Aleyrodina. / Hrsg. GERALD MORITZ: Pflanzensaftsaugende Insekten, Bd. 2. - Hohenwarsleben: Westarp Wissenschaften Verlagsgesellschaft mbH, 2002. - 240 S.: 82 Abb., 35 Tab, 1 Farbtaf. - (Neue Brehmbücherei; Bd. 664). - ISBN 3-89432-888-6

Mottenschildläuse sind zwar den meisten Entomologen bekannt, sie finden aber wegen ihrer geringen Größe und weil sie keine attraktiven Sammlungsobjekte sind, wenig Beachtung. Dabei sind sie als Pflanzenschädlinge in wärmeren Ländern und in Gewächshäusern von überaus großer und in neuester Zeit durch weitere Verschleppung und Dezimierung ihrer Gegenspieler zunehmender Bedeutung. Bis 1978 waten bereits 1156 Arten bekannt, und ihre Zahl steigt weiterhin. Der Autor, der schon durch eine Reihe von Veröffentlichungen über Mottenschildläuse hervorgetreten ist, lässt hinsichtlich der gebotenen Informationsfülle keine Wünsche offen. Mitteleuropäische Arten werden unter Angaben der Wirtspflanzen und des Voltinismus eingehend beschrieben. Am besten bestimmen lassen sich die Puparien, für die es eine illustrierte Bestimmungstabelle gibt. Morphologie und innere Organe der Imagines werden ausführlich behandelt. Selbstverständlich kommen auch (teilweise parthenogenetische) Fortpflanzung und Entwicklung zur Sprache. Der Jenaer Tradition entsprechend wird dabei besonders auf Ökomorphosen und Dormanzformen eingegangen.

Schäden werden zunächst durch Nährstoffentzug verursacht. Der Honigtau, der zur Schadwirkung beiträgt, wird nicht von Ameisen ausgebeutet, so dass er für Schwärzepilze zur Verfügung steht. 1990 waren bereits 70 durch Mottenschildläuse übertragene Virosen bekannt.

Von den ebenfalls ausführlich berücksichtigten Gegenspielern haben sich einige Parasitoide in der biologischen Bekämpfung bewährt. Überraschend ist es, dass von Bemisia tabaci nicht weniger als 53 parasitische Chalcidoidea, hauptsächlich Aphelinidae, bekannt sind. Für die Bekämpfung kommen auch Pilze in Frage. Einem sehr umfangreichen Literaturverzeichnis folgen zwei sehr nützliche Anhänge: Der erste listet die europäischen Arten unter Angabe des Votkommens in den einzelnen Länder auf, der zweite führt im Weltmaßstab die schädlichen Arten mit Angaben zu Verbreitung und Wirtspflanzen an. Fazit: Das Buch scheint geeignet, neue Interessenten für die Mottenschildläuse zu gewinnen. Es sollte in keiner entomologischen Bibliothek fehlen. 